American Journal of Applied Sciences 6 (2): 204-213, 2009

ISSN 1546-9239

(C) 2009 Science Publications

\title{
A Critical Review of Global Wind Power Generation
}

\author{
${ }^{1}$ T. Ahilan, ${ }^{2}$ Dr. K.P. Mohammed and ${ }^{3}$ Dr. S. Arumugham \\ ${ }^{1}$ Department of Mechanical Engineering, \\ Dr. Sivanthi Aditanar College of Engineering, Tiruchendur-628215, Tamil Nadu, India \\ ${ }^{2}$ Former Director (R and D), B.S. Abdur Rahman Crescent Engineering College, \\ Vandaloor,Chennai-600048, Tamil Nadu, India \\ ${ }^{3}$ PET Engineering College, Vallioor-627117, Tirunelveli District, Tamil Nadu, India
}

\begin{abstract}
This research begins with an overview of wind development and installation-related trends, including trends in capacity growth. Development of wind power has reached a level of maturity, which could be taken upon for further novelty and growth in meeting the future energy needs in much greater proportion. Current research techniques are producing stronger, lighter and more efficient blades for the turbines. Computer-controlled wind plants give optimum power output from available winds. With respect to new capacity, wind power is currently one of the most inexpensive ways to produce electricity and it may have a significant role to play in a carbon-constrained world. The kinetic energy in the wind is a promising source of renewable energy with significant potential in many parts of the world. The energy that can be captured by wind turbines is highly dependent on the local average wind speed. The research reviews the global development of wind energy, development of the technology of wind turbines and the various parameters related to wind energy conversion. Many countries are expanding their dependency over wind energy for the production of electricity and this process is increasing exponentially year after year. The research also reviews the past, ongoing and future technological developments in wind energy conversion systems.
\end{abstract}

Key words: Wind power, wind speed, wind turbine technology

\section{INTRODUCTION}

Wind turbine is a non-polluting means of generating electricity. Large-scale modern wind turbines are presently able to produce electricity in the United States at economically competitive rates in a significant portion of the country, depending upon the average wind speed of the location of the turbine. The production cost at a given location depends predominantly upon the wind speed and to a lesser extent the type, size and configuration of the turbines. The placement of wind turbines in offshore locations is a relatively recent occurrence and it is an offshoot of commercial wind turbine development. The necessary conditions where offshore wind farms make sense are the combination of a strong wind resource, large areas of shallow waters located near land in an area where a demand for the electricity exists. Since installation in water is more expensive than land installation, the wind resource must be sufficient to cover the added cost.

The wind energy boom includes more and more countries. Wind turbine technology has reached a mature status during the past 15 years as a result of international commercial competition, mass production and continuing technical success in $\mathrm{R}$ and $\mathrm{D}$. The earlier concerns that wind turbines were expensive and unreliable have largely been allayed. Wind energy project costs have declined and wind turbine technical availability is now consistently above $97 \%$. Wind energy project plant capacity factors have also improved from $15 \%$ to over $30 \%$ today, for sites with a good wind regime ${ }^{[1]}$. With nearly 74,000 Mega Watts (MW) installed all over the world by the end of 2006. In 2005-06, the annual capacity additions worldwide nearly 14,900 MW. After 14,900 MW additional capacity, the global rate of growth increased to $31.66 \%$ in the year 2006. With this growth rate continuing, one expects $1,60,000 \mathrm{MW}$ to be installed worldwide by the year $2010^{[2]}$. Over the last three years or so India has added more than 4,500 MW of wind power generation capacity accounting for more than $60 \%$ of the total installed capacity of 7,280 MW. Due to this growth, India is ranked fourth in the world, has more wind power generation capacity than Denmark and has

Corresponding Author: T. Ahilan, Department of Mechanical Engineering, Dr. Sivanthi Aditanar College of Engineering, Tiruchendur-628215, Tamil Nadu, India Tel: +919443527560 
Am. J. Applied Sci., 6 (2): 204-213, 2009

almost more than double the capacity on nuclear power in the country itself. The Clean Development Mechanism (CDM) of the Kyoto Protocol provides industrialized countries with an incentive to invest in emission reduction projects in developing countries to achieve a reduction in $\mathrm{CO}_{2}$ emissions at lowest cost that also promotes sustainable development in the host country. Wind power projects could be of interest under the CDM because they directly displace greenhouse gas emissions while contributing to sustainable rural development, if developed correctly.

Many of these countries can use wind energy in standalone or hybrid mode to meet the rural electrification needs. On the other end of the spectrum are countries like the UK Ireland, Canada, New Zeland, Scandinavian countries and Russia perhaps in the northern latitudes. There are excellent wind resources, but these countries have not been as forthcoming in wind power development as Germany, which has the largest wind farm installations in the world but not the best wind resources ${ }^{[3]}$.

\section{IMPORTANCE OF WIND ENERGY}

With more and more evidence coming to light about the adverse effects of concentrated amounts of $\mathrm{CO}_{2}$ in the atmosphere we would know that we need to change the way in which we produce the majority of our energy, i.e. burning of fossil fuels. This need for change led to introduction of the Kyoto accord; a legally binding agreement dedicated to reduction of $\mathrm{CO}_{2}$ emissions. With respect to the geographic location, for instance there doesn't seem to be many places where hydro dams and reservoirs can be installed in Denmark or the Netherlands, the same goes for solar where the northern European climate will limit its impact. As for wave power; well it hasn't proved itself yet despite the fact that it has been around for some time now. That leaves wind; wind has been seen as the fastest way to make an impact on increasing a country's share of renewable energy and reducing emissions, making wind the renewable energy of choice. Solving many of the environmental and energy problems in industrialized countries, the growth of wind energy has been fuelled by this increased awareness of both public and private parties in environmentally friendly energy technology. Nationally, there have been increasing efforts to promote renewable energy as a response to the awareness of the limited supply of fossil fuels and also to meet the growing energy demand. State and local governments as well as the federal government have realized that not only can renewable energy be a way to meet future energy demands but also could
Table 1: Emissions factors of gas, coal and wind technologies (lb/MWh)

\begin{tabular}{llll}
\hline Pollutant & Advanced coal & Advanced gas & Wind \\
\hline Sulphur Oxides & 0.83 & 0 & 0 \\
Nitrogen Oxides & 1.82 & 0.61 & 0 \\
Particulates & 0.14 & 0.10 & 0 \\
\hline
\end{tabular}

promote economic growth in rural communities, some of the hardest hit areas with job losses and declining population in recent years.

Carbon emission reduction from electric generation to the level required to stabilize atmospheric carbon concentration, most effectively achieved through a combination of natural gas, energy efficiency and renewable energy is tabulated in Table 1. Wind energy is a clean source that provides electricity with virtually no $\mathrm{CO}_{2}$ emissions. Wind along with displacement of carbon dioxide, also displaces other harmful emissions contributing to smog, acid rain and airborne particulates. Though the combustion of natural gas produces no sulphur oxide emissions, it does produce significant amounts of nitrogen oxides and particulates as well as about $40 \%$ of carbon emissions produced by coal. Wind technology provides an outstanding opportunity to cut carbon dioxide output at reasonable cost. In addition to helping the various countries to meet its greenhouse reduction goals, setting up of wind turbines will result in healthier air and water for millions of people and in the conception of new jobs.

\section{WIND POWER GENERATION TECHNOLOGY}

Power is available from the kinetic energy of the mass of air moving in wind. The amount of energy that wind carries increases by a power of two as its speed increases and is proportional to the mass of air that passes through the plane of the area swept by the rotors. As power is the product of energy (work) within a given time frame, the power of wind increases by a power of three as the speed of wind increases. Because of the low density of air, the power density of wind is much lower than that of waterpower for instance. The power that can be harvested from wind is calculated in terms of the swept area, for a horizontal axis wind turbine, the area through which the rotor blades pass. Wind turbines are specially built to make use of wind which ranges in speed between 3 to $30 \mathrm{~m} \mathrm{sec}^{-1}$. Higher wind speed can damage the turbine so large turbines are equipped with the brakes. Smaller turbines can make use of wind speeds lower than $3 \mathrm{~m} \mathrm{ses}^{-1}$. The power of the wind is plotted in Fig. 1 at various wind speeds in standard conditions (dry air, density $1.225 \mathrm{~kg} \mathrm{~m}^{-3}$, at sea level pressure). 
Am. J. Applied Sci., 6 (2): 204-213, 2009

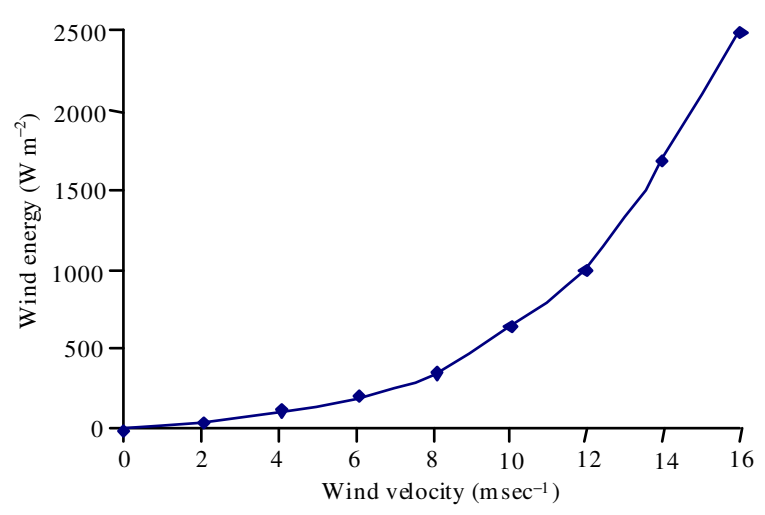

Fig. 1: Wind speed scale

The power in the wind is proportional to:

- The area being swept by the wind turbine blade

- The cube of the wind speed

- The air density-which varies with altitude

The formula used for calculating the power is:

$$
\mathrm{P}=0.5 \times \rho \times \mathrm{A} \times \mathrm{C}^{3}
$$

Where:

P: Power in watts (W)

$\rho$ : The air density in $\left(\mathrm{kg} \mathrm{m}^{-3}\right)$, (about $1.225 \mathrm{~kg} \mathrm{~m}^{-3}$ at sea level, less higher up)

A: The swept rotor area in $\left(\mathrm{m}^{2}\right)$

C: The wind speed in $\left(\mathrm{m} \mathrm{sec}^{-1}\right)$

The fact that the power is proportional to the cube of the wind speed is very significant. This can be demonstrated by pointing out that if the wind speed doubles then the power in the wind increases by a factor of eight. It is therefore worthwhile finding a site, which has a relatively high mean wind speed.

The actual power that can be extracted from the wind is significantly less than what this figure suggests. The actual power will depend on several factors, such as the type of machine and rotor used, the sophistication of blade design, friction losses and the losses in the pump or other equipment connected to the wind machine. There are also physical limits to the amount of power that can be extracted realistically from the wind. It can be shown theoretically that any windmill can only possibly extract a maximum of $59.3 \%$ of the power from the wind. In reality, this figure is usually around $45 \%$ (maximum) for large electricity producing turbine and around $30 \%$ to $40 \%$ for a wind pump.
So, modifying the formula for 'Power in the wind' we can say that the power, which is produced by the wind machine, can be given by:

$$
P_{m}=0.5 \times C_{p} \times \rho \times A \times C^{3}
$$

Where:

$\mathrm{P}_{\mathrm{m}}$ : Power (in watts) available from the machine

$\mathrm{C}_{\mathrm{p}}$ : The coefficient of performance of the wind machine (power efficiency)

The wind turbine technology has a unique technical identity and unique demands in terms of the methods used for design ${ }^{[4]}$. The behaviour of a modern wind turbine is made up of a complex interaction of components and subsystems and its design requires the skills of a multidisciplinary team of engineers with expertise in diverse areas: atmospheric wind flow, rotor aerodynamics, control, mechanical systems, electrical systems and civil engineering. Modern wind turbines are based on the principle of aerodynamics and are designed to deliver energy across a range of wind speeds and at lower costs. This technology improves wind capture, reduces stresses and lengthens turbine life $^{[5]}$.

Wind has considerable amount of kinetic energy when blowing at high speeds. This kinetic Energy when passing through the blades of the wind turbines is converted into mechanical energy and rotates the wind blades and the connected generator, thereby producing electricity. A wind turbine primarily consists of a main tower, blades, nacelle, hub, main shaft, gearbox, bearing and housing, brake and generator. The main tower is $50-100 \mathrm{~m}$ high. Generally, three blades made up of Fiber Reinforced Polyester are mounted on the hub, while in the nacelle the major parts are housed. Under normal operating conditions the nacelle would be facing the upstream wind direction ${ }^{[6]}$. The hub connects the gearbox and the blades. Solid high carbon steel bars or cylinders are used as main shaft. The gearbox is used to increase the speed ratio so that the rotor speed is increased to the rated generator speed ${ }^{[7]}$; it is the most critical component and needs regular maintenance. Oil cooling is employed to control the heating of the gearbox. Gearboxes are mounted over dampers to minimize vibration. Failure of gearbox may put the plant out of operation for an entire season, as spares are often not available. Thus, new gearless configurations have become attractive for wind plant operators. Modern turbines fall into two basic groups: horizontal axis turbines and vertical axis turbines. Horizontal axis turbines resemble airplane propellers, 
with two to three rotor blades fixed at the front of the tower and facing into the wind. This is the most common design found today, making up most of the large utility-scale turbines on the global market. Vertical axis turbines resemble a large eggbeater with rotor blades attached vertically at the top and near the bottom of the tower and bulging out in the middle ${ }^{[8]}$. Significant areas of the world have mean annual wind speeds of above 6-7 $\mathrm{m} \mathrm{sec}^{-1}$ which makes small-scale wind powered electricity generation an attractive option $^{[9]}$.

Evolution of the wind turbine industry: Wind has been used as a natural source of energy for many years. The use of wind energy dates back to the dawn of civilisation when sailing vessels were powered by the wind. The first simple sailboats were set afloat in Egypt about 5,000 years ago. Around the year 700 AD, the first wind machines rotating around a vertical axis were employed to grind grain. The famous fixed-tower windmills with sails provided irrigation for many parts of the Mediterranean islandof Crete. Wind-driven gristmills were one of the greatest technical challenges of the middle Ages. In the 14th century, the Dutch improved on the design that had spread throughout the Middle East and continued to use it for its primary purpose of grinding grain. A wind powered water pump was introduced in the United States in 1854. It was the familiar fan type with many vanes around a wheel and a tail to keep it pointed into the wind. In 1882, Charles Brush built the windmill designed to produce electricity. Brush's Turbine consisted of 144 cedar planks with a diameter of $17 \mathrm{~m}$, had an output of $12 \mathrm{kw}$ and produced electricity for 20 years. By 1940, over 6 million of these windmills were being used in the United States mainly for pumping water and generating electricity. The Wild West was won at least in part with the help of these wind pumps that were used to supply water for the massive herds of cattle. However, the 20th century soon brought an end to the widespread use of wind energy, which gave way to the modern energy resources, oil and electricity. It was not until after the oil crisis that wind energy options met with renewed interest. As a result of the drastic rise in oil prices at the beginning of 1970s, energy planners have once again been turning their attention increasingly to the utilization of wind energy. State-sponsored research and development grants in many countries have provided a fresh stimulus to the development of technology for the utilization of wind energy. Efforts have been concentrated on developing wind energy converters for generating electricity, because in the industrialized countries the application of wind pumps is of minor importance. According to the International Energy Agency (IEA, 2001a), renewable energy sources excluding hydro, combustible renewable and waste contributed just $0.5 \%$ of the total primary energy supplies in 1999. This category includes wind energy, geothermal, solar and others. The phenomenal growth of this industry can be attributed, primarily, to the rapid progress made in wind turbine technology. Technological progress has led to the development of turbines with high power capture efficiency. However global installed wind capacity is increasing rapidly. Current global installed capacity exceeds 74000 MW with a projected growth rate of greater than $30 \%$ year $^{-1}$. Figure 2 shows the development of wind turbine industry and its forecasting up to 2010. If the same growth rate continues, at the end of 2010 the global installed capacity is nearby 160,000 MW. Also Fig. 3 indicates the global annual addition, installed capacity and prediction in wind turbine industry up to 2010 .

Technical potential of wind energy in India: The International Energy Agency predicts that the world's energy needs will be about $60 \%$ higher than they are

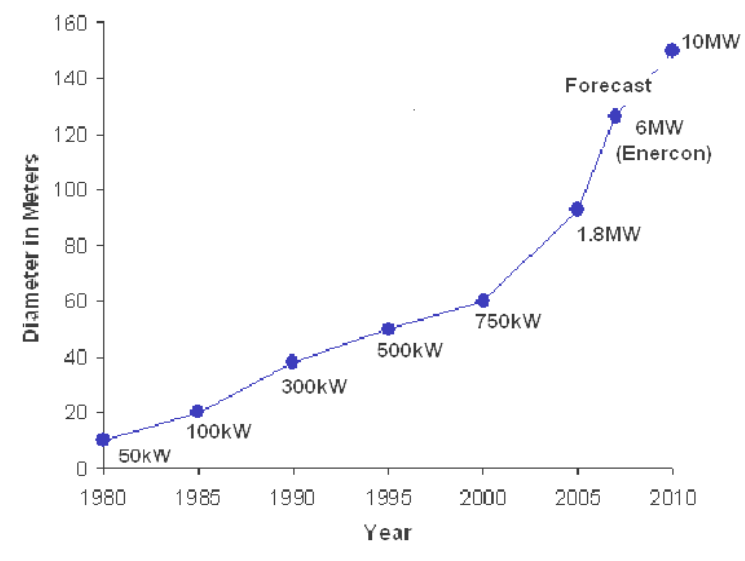

Fig.2: Wind turbine and its development

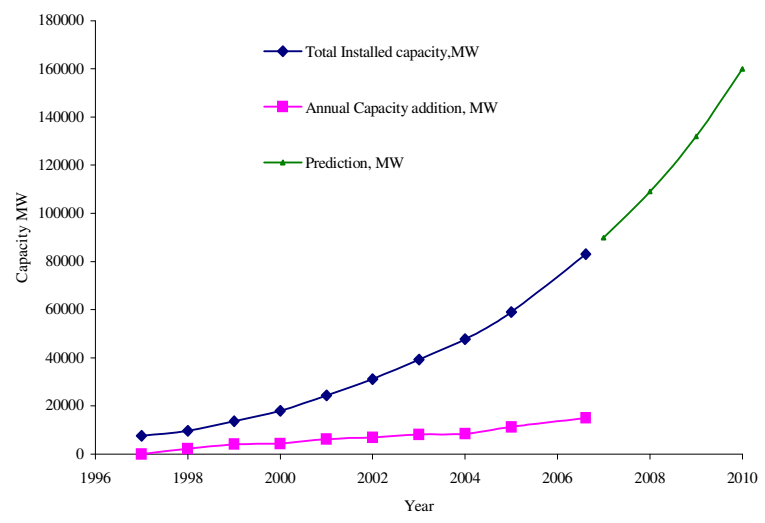

Fig. 3: Total installed capacity and prediction throughout the global 
Am. J. Applied Sci., 6 (2): 204-213, 2009

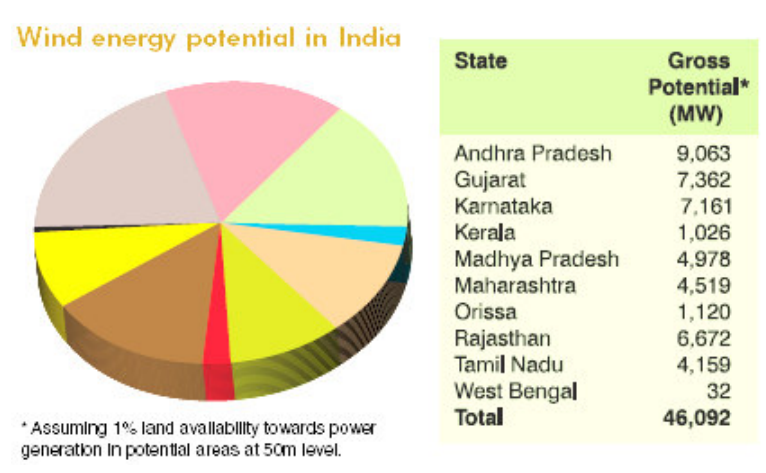

Fig. 4: Wind energy potential in India

now $^{[10]}$. Over the last three years or so, India has added more than 4,500 MW of wind power generation capacity accounting for more than $60 \%$ of the total installed capacity of 7,280 MW. This therefore has been a high growth period and today India is ranked fourth in the world, has more wind generation capacity than Denmark and has almost more than double the capacity based on nuclear power in the country itself. In 2006, the capacity of power plant in India was $124 \mathrm{GW}$, of which $66 \%$ thermal, $25 \%$ hydro, $3 \%$ nuclear and $5 \%$ new renewable ${ }^{[11]}$. Chinese power capacity reached over $600 \mathrm{GW}^{[12]}$, showing India's backlog. In the best locations, wind is already competitive with new coalfired plants. Individual wind turbines have also increased in capacity, with the standard commercial machines reaching $2.5 \mathrm{MW}$ and prototypes for offshore plants even $5 \mathrm{MW}$. A notable feature of the Indian programme has been the interest among private investors/developers in setting up of commercial wind power projects. The gross potential is 46,000 MW (source MNES) and a total of about 7280 MW of commercial projects have been established until June 2007. Figure 4 shows the gross potential with respect to all states in India. In particularly, the installed capacity is very close to Gross potential in Tamil Nadu.

A notable feature of the Indian programme has been the interest among private investors/developers in setting up of commercial wind power projects. The gross potential is 45,000 MW (source MNES) and a total of about $7200 \mathrm{MW}$ of commercial projects have been established until June 2007. Figure 5 shows statewise trends in cumulative installations till June 2007.

The total current wind capacity in India is $7.1 \mathrm{GW}$ (as on March 07) growing at $40 \%$ per annum (the fastest among all sources of energy in the country, though from a lower base). The country ranks 4 th in wind power capacity worldwide (Table 2). India is estimated to have a theoretical potential of $65 \mathrm{GW}$ and a technical potential of $15 \mathrm{GW}$. A target of $10.5 \mathrm{GW}$ of capacity addition from wind has been set till 2012 .

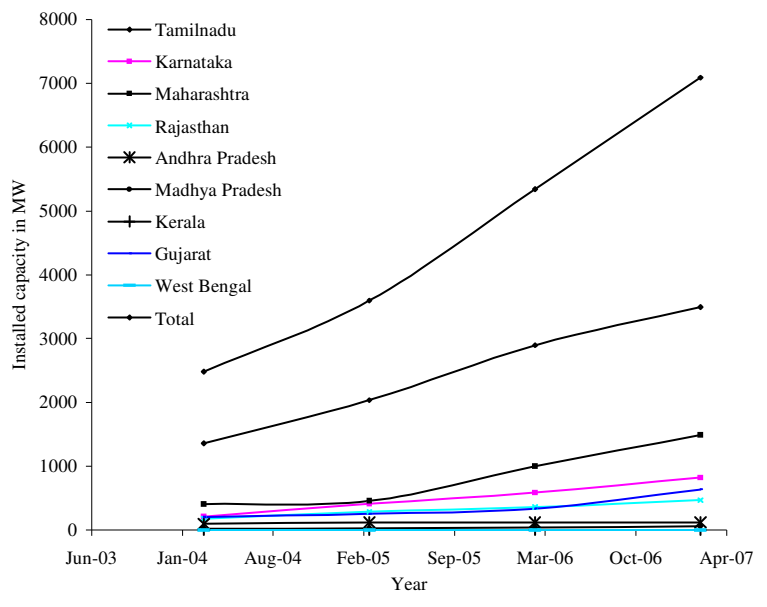

Fig. 5: Installed capacity of all regions in India

Table 2: Ranking of countries according to total capacity Installed wind power capacity (MW)

\begin{tabular}{lllll} 
Rank & Nation & 2005 & 2006 & Latest \\
\hline 1 & Germany & 18.415 & 20.622 & 21.283 \\
2 & Spain & 10.028 & 11.615 & 12.801 \\
3 & US & 9.149 & 11.603 & 13.885 \\
4 & India & 4.430 & 6.270 & 7.231 \\
5 & Denmark (Faeroe Islands) & 3.136 & 3.140 & \\
6 & China & 1.260 & 2.604 & 2.956 \\
7 & Italy & 1.718 & 2.123 & \\
8 & UK & 1.332 & 1.963 & 2.293 \\
9 & Portugal & 1.022 & 1.716 & 1.874 \\
10 & Canada & 683 & 1.459 & 1.670 \\
11 & Rest & 7.916 & 10.929 & 4995 \\
& World total (MW) & 59.089 & 74.044 & 68.988 \\
\hline
\end{tabular}

Wind energy in USA, Spain, Germany and Denmark: In recent years, the United States has added more wind energy to its grid than any other single country and additional capacity 3 gigawatts (3,000 megawatts) is added in 2007. Texas has become the leader in wind energy production. Iowa and Minnesota are expected to each produce one gigawatt by late- $2007^{[13]}$. Wind power generation in the US was up $31.8 \%$ in February, 2007 from February, 2006 $6^{[14]}$. The average output of one megawatt of wind power is equivalent to the average electricity consumption of about 250 American households. According to the American Wind Energy Association, wind generated enough electricity to power $0.4 \%$ (1.6 million households) of total electricity in US, up from less than 0.1\% in 1999. Spanish Energy and Construction firm Acciona, the world's largest wind power developer, has acquired exclusive rights to develop 1,300 MW worth of wind assets is Illinois, Lowa and Wisconsin form US firm. Acciona expects to install $150 \mathrm{MW}$ or more from this pipeline in 2008 alone. 
Am. J. Applied Sci., 6 (2): 204-213, 2009

Table 3: United States: Key statistics

\begin{tabular}{ll}
\hline Total installed wind generation & $11.575 \mathrm{MW}$ \\
New wind generation installed & $2.454 \mathrm{MW}$ \\
Total electrical output from wind & $31 \mathrm{TWh}$ \\
Wind generation as \% of national electric demand & $0.1 \%$ \\
Target & $\mathrm{NA}$ \\
\hline
\end{tabular}

The US wind industry maintained its global lead for new wind energy installations in 2006 with 2,454 MW of new generating capacity (Table 3). The new capacity brought the total national capacity to 11,575 MW and put the United States in third place for highest total installed capacity behind Germany with 20,622 MW and Spain with 11,615 $\mathrm{MW}^{[15]}$.

Approximately 53 new projects were installed in 22 states that commissioned more than 1,535 wind turbines in 2006. The average size of the turbines Installed in 2006 was $1.6 \mathrm{MW}$. With a $27 \%$ growth rate in 2006, wind energy was the second largest source of new power capacity in the country, contributing $19 \%$ of the total new capacity built. Natural gas was the largest contributor with 9,000 MW of new capacity and coal was the third with $600 \mathrm{MW}$. The current capacity will generate approximately 31 million megawatt $\mathrm{h}$ year ${ }^{-1}$, enough to provide power for 2.9 million US homes and displace approximately 23 million tons of carbon dioxide that would have been emitted by traditional resources $^{[15]}$. In support of the initiative, the American Wind Energy Association (AWEA) is working with the US Department of Energy (DOE), the National Renewable Energy Laboratory (NREL), utilities, wildlife advocates, environmental organizations, technology companies, foundations, consumer groups and investors to evaluate credible scenarios for providing up to $20 \%$ of US electric demand with wind power. To provide $20 \%$ of the nation's electricity supply, US wind capacity would have to increase from its current $11.6 \mathrm{GW}$ to about $350 \mathrm{GW}$. A goal of the DOE Wind Energy Program's Wind Powering America (WPA) project is to have 30 states with more than $100 \mathrm{MW}$ of generating capacity by $2010^{[16]}$. There are currently commercial wind-power facilities in 30 states (Fig. 6). Twenty states have more than $50 \mathrm{MW}$ and 16 have more than $100 \mathrm{MW}$. The 5 states with the most generating capacity are:

- $\quad$ Texas with 2,739 MW

- California with 2,376 MW

- Iowa with $931 \mathrm{MW}$

- Minnesota with $895 \mathrm{MW}$

- Washington with $818 \mathrm{MW}$

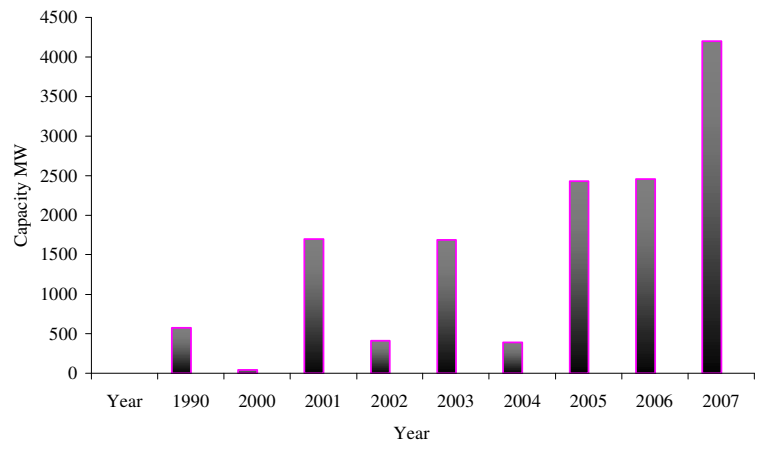

Fig. 6: United States wind power capacity additions

German market's performance has been superior to that of American market. German market policies encouraging renewable energy have been in place continuously for many years. Accordingly, Germany leads the world in installed wind energy capacity and has a thriving and successful local industry that is exporting a range of technologies and services around the globe. By 2010, the World Wind Energy Association expects $160 \mathrm{GW}$ of capacity to be installed worldwide, up from $73.9 \mathrm{GW}$ at the end of 2006 , implying an anticipated net growth rate of more than $21 \%$ year $^{-1}$. Germay, Spain the United States, India and Denmark have made the largest investments in wind generated electricity. Denmark is prominent in the manufacturing and use of wind turbines, with a commitment made in the 1970 s to eventually produce half of the country's power by wind. Denmark generates over $20 \%$ of its electricity with wind turbines, the highest percentage of any country and is fifth in the world in total wind power generation (but Denmark is 56th on the List of countries by electricity consumption). Denmark and Germany are leading exporters of large ( 0.66 to $5 \mathrm{MW})$ turbines.

Germany was the leading producer of wind power with $28 \%$ of the total world capacity in 2006 (7.3\% of German electricity); the official target is for renewable energy to meet $12.5 \%$ of German electricity needs by 2010.This target may be reached even earlier. Germany has 18,600 wind turbines, mostly in the north of the country, including three of the biggest in the world, constructed by the companies Enercon (6 MW), Multibrid (5 MW) and Repower (5 MW). Germany's Schleswig-Holstein province generates $36 \%$ of its power with wind turbines.In some countries (Spain and Denmark) wind supplies $10 \%$ or more of the nation's electricity. According to the German wind power association growth in German market was witnessed after a period of three years, bringing the total installed capacity in Germany to 20621.9 MW. Repowering or 
Am. J. Applied Sci., 6 (2): 204-213, 2009

Table 4: Wind power target projections

\begin{tabular}{|c|c|c|c|c|c|c|c|c|c|c|c|}
\hline Year & 2000 & 2001 & 2002 & 2003 & 2004 & 2005 & 2006 & 2007 & 2008 & 2009 & 2010 \\
\hline New capacity (MW) & & 4.500 & 5.700 & 5.900 & 6.100 & 6.300 & 6.450 & 6.600 & 6.750 & 6.900 & 7.000 \\
\hline Cumulative capacity (MW) & 12.800 & 17.300 & 23.000 & 28.900 & 35.000 & 41.300 & 47.750 & 54.350 & 61.100 & 68.000 & 75.000 \\
\hline Annual growth of new capacity & & & $26.7 \%$ & $3.5 \%$ & $3.4 \%$ & $3.3 \%$ & $2.4 \%$ & $2.3 \%$ & $2.3 \%$ & $2.2 \%$ & $1.4 \%$ \\
\hline Annual growth of cumulative capacity & & $35.2 \%$ & $32.9 \%$ & $25.7 \%$ & $21.1 \%$ & $18 \%$ & $15.8 \%$ & $13.8 \%$ & $12.4 \%$ & $11.3 \%$ & $10.3 \%$ \\
\hline
\end{tabular}

replacement of old turbines with new ones and off shore wind farms are likely to fuel further development in Germany.

Table 4 detail the new industry targets which outline that the annual installation rate will continue to increase, but at lower rates. The high growth of the last years has been based mainly on the German and Spanish markets. Market forecasts for the next few years indicate that annual installations will stabilise in Spain and will decrease in Germany. A 3.5\% increase in annual installations is assumed for the year 2003, which decreases gradually to $1.4 \%$ in 2010. This corresponds to a $25.7 \%$ increase in total installed capacity in 2003 gradually decreasing to $10.3 \%$ in the year 2010 .

Five countries added more than $1000 \mathrm{MW}$ : the united states of America (2.454 MW), Germany (2,194 MW), India (1,840 MW) and Spain (1,587 MW) were able to secure their leading market positions and china $(1,145 \mathrm{MW})$ joined the group of the top five markets and is now number five in terms of added capacity.

The electricity output from the wind targets is expressed in Fig. 7 in terms of the equivalent amount of household electricity consumed by the average individuals or households in Europe. The calculations are based on official data and forecasts from Eurostat and Eurelectric and the European Commission's "Energy Outlook to 2020 report. These forecasts assume that whilst population and number of households increase by only a small amount, average household electricity consumption increases by $16 \%$ by 2010 and by $30 \%$ by 2020 . The number of people per household declines by 2020. Based on these calculations, the wind power productions at various years like 2001, 2002, 2006, 2010 and 2020 are calculated as 18.91, 44.8, 85.5, 167.4 and 425 Twh. Also the contribution of wind power $(\mathrm{GW})$ to electricity generation capacity in 1995 to 2020 is estimated as $1995-0.45 \%, 2000-9.1 \%, 2010-10.6 \%$ and $2020-21 \%$. In 2020, for example, wind power will generate $425 \mathrm{TWh}$; this is $50 \%$ of the forecast EU household electricity consumption in 2020 , but $66 \%$ of that consumed in 2001. With respect to the development of wind power production, the annual $\mathrm{CO}_{2}$ emission reduction from wind power was calculated up to 2010 and plotted in Fig. 8.

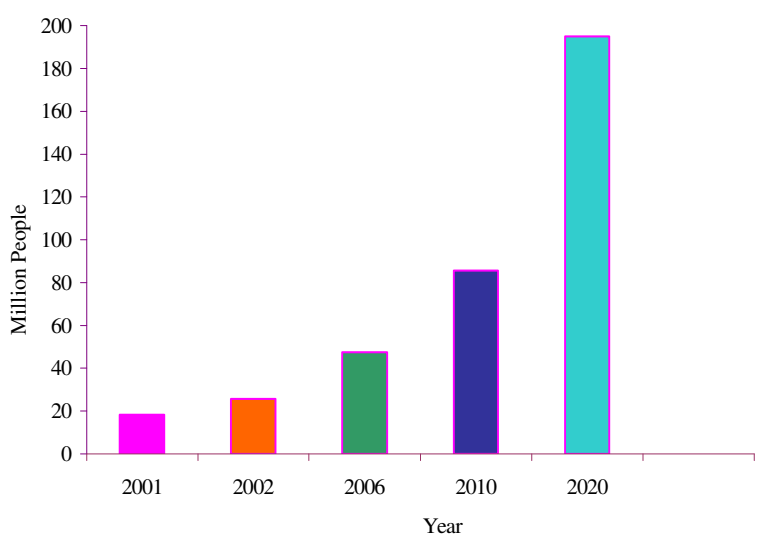

Fig. 7: Equivalent Electricity needs met by wind power 2001-2020

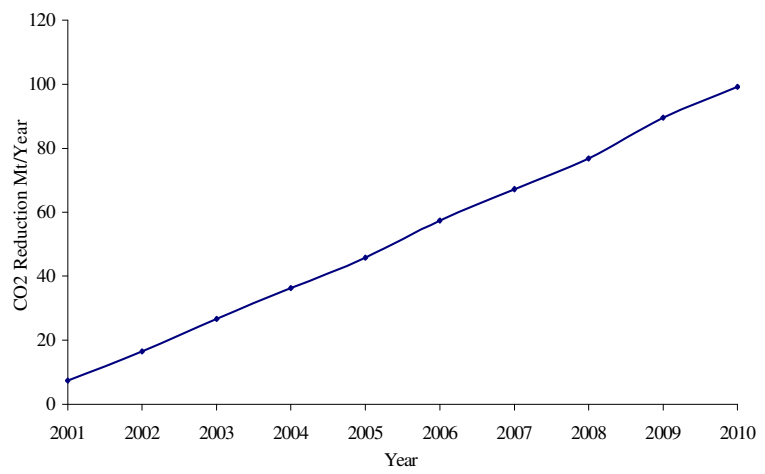

Fig. 8: Annual $\mathrm{CO}_{2}$ emission reductions from wind power

The Danish electricity system, consisting of power plants, transmission and distribution systems, is consumer owned through co-operatives or indirectly via municipal ownership. These utilities are mostly nonprofit organizations with profits being back to consumers through lowering of electricity prices. In a Danish energy plan from 1976 wind energy was planed to cover $4 \%$ of Danish electric consumption. In the following energy plan this share was planned to be $8 \%$ by 2000 . Today, this share is $18,8 \%$. The most recent Danish energy plan states that in 2030 renewable energy sources should provide $50 \%$ of the energy consumption. The largest part of this is planned to come from wind energy. 
Other countries contribution: New Zeland's wind industry is optimistic about the success of a sustainable future being outlined by the government and its desire to develop an energy strategy that provides an efficient, secure and affordable energy supply while facing up to the responsibilities regarding climatic change. The New Zeland Energy strategy (NZES) 2050 offers an opportunity for the government and the electricity industry to set direction for the country in mature, wellestablished manner and is continuously growing. Due to the level of development, wind energy should perpetually provide auditioned generation capacity rather than any other form of renewable energy. At present it has about $170 \mathrm{MW}$ of wind power capacity.

For decades Egypt has been the leading wind energy country of the continent. According to announcement from government of Egypt, $750 \mathrm{MW}$ will be installed per year for the next five years. By 2020 wind energy has to cover $20 \%$ of the total national electricity capacity with wind energy representing an estimated 13GW. Most important is that Egypt most likely will require up to $80 \%$ local production of the value of the wind turbines to obtain in market access. Most of the wind turbines within the new program will be installed along the Red sea with among annual wind speeds of up to $10 \mathrm{~m} \mathrm{sec}^{-1}$ allowing capacity factors of $42 \%$. Extensive experience with wind energy has been obtained in this region since the first wind turbines were installed in 1993. In 1996, a series of wind turbines were installed using blades and other components with a total of $40 \%$ manufactured in Egypt. The stations are listed from north to south: Abu Darag, Zafarana and Gulf of El-zayt are situated along the Gulf of Suez, Hurghada in the north-most part of the Red sea. An overall summary of wind climates measured at four main stations is given in Table 5 .

The first wind energy demonstration wind force was established in Ras Ghareb on the Red sea coast, with $400 \mathrm{KW}$ capacity. In addition, a 5.2 MW wind farm in Hurghada is operating successfully containing different designs and sizes of wind turbines (10-300 KW). The wind farm is connected to local electricity grid of the city and produces more than 15 million $\mathrm{KWh} /$ Year.

Table 5: Wind data at various stations in Egypt

\begin{tabular}{lllll}
\hline & $\begin{array}{l}\text { Data } \\
\text { recovery } \\
\text { rate } 12 \%\end{array}$ & $\begin{array}{l}\text { Mean wind } \\
\text { speed } \mathrm{U} \\
\left(\mathrm{M} \mathrm{sec}^{-1}\right)\end{array}$ & $\begin{array}{l}\text { Mean energy } \\
\text { density }\end{array}$ & $\begin{array}{l}\mathrm{E}\left(\mathrm{W} \mathrm{m}^{-2}\right) \\
\text { Direction }\end{array}$ \\
\hline D (Deg)
\end{tabular}

In 2005, China announced it would build a 1000 MW wind farm in Hebei for completion in 2020. China reportedly has set a generating target of 20,000 MW by 2020 from renewable energy sources-it says indigenous wind power could generate up to $253,000 \mathrm{MW}$. In late 2005, the Chinese government increased the official wind energy target for the year 2020 from 20-30 $\mathrm{GW}^{[17]}$ (Fig. 9).

Another growing market is Brazil, with a wind potential of $143 \mathrm{GW}$. The federal government has created an incentive program, called Proinfa, to build production capacity of $3300 \mathrm{MW}$ of renewable energy for 2008, of which 1422 MW through wind energy. The program seeks to produce $10 \%$ of Brazilian electricity through renewable sources.France recently announced a very ambitious target of $12500 \mathrm{MW}$ installed by 2010 .

Canada has become world's 12th largest nation in terms of installed wind energy capacity by more than doubling its installed capacity to $1,460 \mathrm{MW}$ by the end of year 2006. Canada experienced rapid growth of wind capacity between 2000 and 2006, with total installed capacity increasing from 137-1,460 MW and showing an annual growth rate of $38 \%{ }^{[18]}$. Particularly rapid growth has been seen in 2006, with total capacity doubling from the $684 \mathrm{MW}$ at end-2005. This growth was fed by measures including installation targets, economic incentives and political support. The government of Ontario announced that it will introduce a feed-in tariff for wind power, referred to as 'Standard Offer Contracts', which may boost the wind industry across the province. In Quebec, the provincially owned elctric utility plans to purchase an additional $2000 \mathrm{MW}$ by 2013 . If the goal of $10,000 \mathrm{MW}$ installed wind energy is achieved, in addition to the environmental benefits, economic benefits to rural communities across

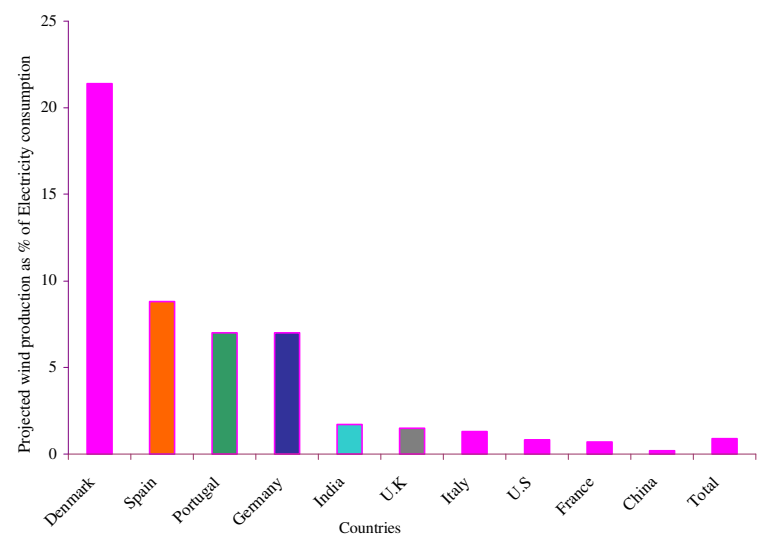

Fig. 9: Wind production as Electricity consumption in various countries 
Am. J. Applied Sci., 6 (2): 204-213, 2009

Canada through investment and job creation, lease income for land owners and a new tax base for municipal government could also be achieved.

Five countries added more that $500 \mathrm{MW}$ and showed excellent growth rates: France (810 MW, $107 \%$ growth) Canada (768 MW, $112 \%$ growth), Portugal (628 MW, 61\% growth) and the United Kingdom (610 MW, 45\% growth). The most dynamic market in 2006, Brazil, faced its long expected take off and added $208 \mathrm{MW}$ that equals a sevenfold increase of installed capacity within one year.

In urban locations, where it is difficult to obtain predictable or large amounts of wind energy, smaller systems may still be used to run low power equipment. Equipment such as parking meters or wireless internet gateways may be powered by a wind turbine that charges a small battery, replacing the need for a connection to the power grid.

\section{SUMMARY}

Manufacturers are developing the next generation of wind turbines in the US and Europe. Government support of markets in Europe, India and other developing countries, has been largely responsible for burgeoning sales, providing manufacturers with cash flow to conduct private development efforts. European manufacturers currently supply most of the world market for utility-scale wind turbines and therefore provide the majority of the private investment in $\mathrm{R}$ and D. Government-sponsored $\mathrm{R}$ and $\mathrm{D}$, through national laboratories, also plays an essential role in developing new wind energy technology. The wind industry, as a whole, is still small enough, in terms of financial resources, to require shared research and testing in certain areas. Continuing applied $\mathrm{R}$ and $\mathrm{D}$ to develop the technical knowledge base necessary to design more cost effective and reliable turbines. Competition will not only be within the wind industry, but against improved fossil generating technologies. Research and testing of current advanced components and subsystems is also critical for manufacturers to compete in nearterm markets.

By 2015 the provincial government plan to setup a minimum of 10,000 MW of wind energy capacity and the Global Wind Energy Council (GWEC) projects that installed wind energy capacity globally will increase to 171,000 MW. According to an estimate, worldwide about 163,000 people are now directly employed by the wind energy industry. In the year 2006, the installed capacity of wind energy worldwide increased by a record 15,197 MW, bringing total wind energy capacity to $74,223 \mathrm{MW}$, enough to power 22.5 million homes.

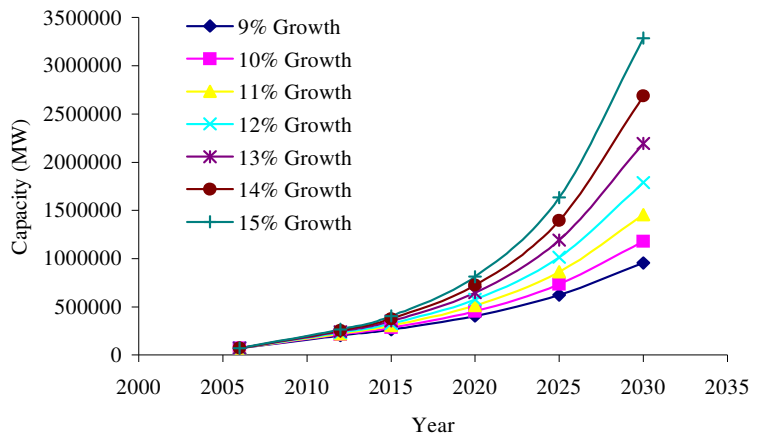

Fig. 10: Projections of installed capacity in India

The Fig. 10 below presents the total installed capacity needed in India assuming at different growth rates. Even if we go by the lower growth rate of $9 \%$, situation becomes rather alarming by 2020. Based on calculations if we go by the growth rate of $15 \%$ at the end of 2030, the installed capacity becomes $3285672 \mathrm{MW}$.

The currently installed wind power capacity generates more than $1 \%$ of the global electricity consumption. Based on the accelerated development, it is predicted that by 2010, 160,000 MW will be installed. These developments and growing trends towards wind energy signal a promising future for the wind energy industries. With its improved technology and superior economics, experts predict wind power could well capture atleast 5\% of the world energy market by the year 2020 .

\section{CONCLUSION}

This research attempts to show the different technology policy and industrial development of the wind turbine industry in various countries throughout the world. The development of wind energy in some countries is flourishing while in others it is not fulfilling the potential that might be anticipated from a simple consideration that the wind resources are complex. This research also emphasizes USA, Spain, Germany, India and Denmark's unique strategy of interactive learning for developing their wind turbine industry. It clearly indicates the case for solution to meet the global requirements through wind turbine industry. The performed growth clearly showed that how the Government, Non renewable energy sectors helps the private sectors to increase the production of wind turbine industry. With the presented method, knowledge of the wind velocity at different scales could be used to calculate the wind power production. This method attempts to address the various country's 
position in the world market, wind resource, gross potential and variation of wind speed with respect to site, different growth rate and indications. We claim that this sectoral innovation systems framework is especially useful tool for analyzing the growth of wind turbine industry and in its essence to preserve the environment with reduction in carbon dioxide emissions.

\section{ABBREVIATIONS}

MW: Mega Watt

GW: Giga Watt

CDM: Clean Development Mechanism

AWEA: American Wind Energy Association

DOE: Department Of Energy

NREL: National Renewable Energy Laboratory

WPA: Wind Powering America

NZES: New Zeland Energy Strategy

GWEC: Global Wind Energy Council

\section{REFERENCES}

1. Michaelowa, A., 2006. Potential of wind power projects under the clean development mechanism in India Purohit. J. Wind Energy.

2. Wind Chronicle-Volume-3 No: 2 and 3 Oct.2006March 2007.

3. In Wind Chronicle-Volume-3 No: 4 April-June 2007.

4. Quarton, D.C., F. Rasmussen, C. Nath and K. Agyriadis, 1996. Wind turbine design calculations-the state-of-the-art. In: European Union Wind Energy Conference, May, Gothenberg, pp: 10 .

5. Power Line, 2000. Winds of change-wind energy promises to be the most cost-effective means of clean power, wind power in India. India's First Monthly Power Magazine, New Delhi, India, 4 (4): 54.
6. Purohit, P.J. and A. Michaelowa, 2007. Potential of wind projects under the clean development mechanism in India. Carbon manag, 2 (1): 8 http://www.zora.unizh.ch.

7. Paul Gipe, 1999. Wind Energy Basics, a guide to small and micro wind Systems: Chelsea Green Publishing Company. www.wind-works.org.

8. International Energy Outlook, 2006. International Energy Agency (IEA), Paris: 2006.

9. Gary, L. and Johnson, 2001. Wind Energy Systems.

10. International Energy Outlook, 2006. International Energy Agency (IEA), Paris: 2006.

11. Ministry of Power, 2006. New Delhi. (http://power.min.nic.in).

12. People's Daily, 2007. China's power generating capacity tops 622 million kilowatts, Jan'03, 2007.

13. http://awea.org/projects.

14. http://www.eia.doe.gov/cneaf/electricity/epm/epm sum.html.

15. US Department of Energy, 2007. Wind Powering America FY06 Activities. Summary www.nrel.gov/docs/fy07osti/40660.pdf.

16. National Wind Coordinating Committee, 2006. Wind Power and Radar Issue Forum July 27, Reno, Nevada.www.nationalwind.org/vents/business/37/i ssuebrief.pdf.

17. Lema, Adrian and Kristian Ruby, 2007. Between fragmented authoritarianism and policy coordination: Creating a Chinese market for wind energy. Energy Policy, 35 (7).

18. Wind Energy: Rapid Growth, 2006. Canadian Wind Energy Association. Retrieved on 2006-04-21. 